УДК 631.95; 58.02; 523.9

(C) 2015

Писаренко П. В., доктор сільськогосподарських наук, професор, Хлебнікова Я. О., аспірант

(науковий керівник - доктор сільськогосподарських наук, професор П. В. Писаренко)

Полтавська державна аграрна академія

\title{
ПРО МОЖЛИВІСТЬ ВПЛИВУ СОНЯЧНОЇ АКТИВНОСТІ НА ВРОЖАЙНІСТЬ СІЛЬСЬКОГОСПОДАРСЬКИХ КУЛЬТУР У ПОЛТАВСЬКІЙ ОБЛАСТІ
}

\section{Рецензент - кандидат сільськогосподарських наук М. А. Піщаленко}

У статті розглянуто роль сонячної активності у формуванні врожаю різних сільськогосподарських культур в агроекологічних умовах Полтавської області. Проаналізовано дані врожайності сільськогосподарських культур з 25-ти районів Полтавської області за 47-річний період (з 1966-го року по 2012 рік) та дані середньомісячної сонячної активності (числа Вольфа) за аналогічний період. Виявлено, щуо максимум сонячної активності та максимум урожайності по всім культурам співпадають у 1989-1991 роках. Встановлено, шо зсув по фазі максимуму врожайності y порівнянні з піком сонячної активності переноситься з 1980 року на 1973-1978 роки. Підкреслюється, щуо високі показники врожайності сільськогосподарських культур можуть спричинятися максимумами сонячної активності. Також проведено кореляиійний аналіз по кожному з изиклів сонячної активності між показниками врожайності та середньомісячними числами Вольфа за вететаційний період сільськогосподарських культур.

Ключові слова: врожайність, сонячна активність, числа Вольфа, максимум, циклічність, вегетаційний період.

Постановка проблеми. Сонце - важливе джерело енергіï для усього живого на нашій планеті. На поверхні та всередині Сонця відбуваються процеси, які як безпосередньо, так і опосередковано впливають на земні події. Одним із таких процесів є сонячна активність. Вона впливає на такі явища, як погодно-кліматичні умови, чисельність тварин, у тому числі і комах, різного роду катастрофи (як природні, так і техногенні та соціальні), поширення епідемій, хвороб i, навіть, на сплески психічної та творчої діяльності людини [4].

Однак досить цікавим питанням $є$ зв'язок урожайності сільськогосподарських культур із сонячною активністю, яке має свою довгу історію. Відомо, що ще в III ст. до н. е. Катон Старший, римський письменник, помітив, що ціни на жито залежали від сонячної активності (від «захмарення Сонця»). За високої сонячної активності врожаї жита були кращими і тому ціни на жито знижувались. У Древній Русі крізь дим лісових пожеж люди бачили «темні плями, аки цвяхи». На початку XVII століття Галілей вперше направив телескоп на Сонце i 3 тих пір почались більш-менш регулярні спостереження сонячних плям. А 3 середини XIX століття ці спостереження велися щоденно, якщо дозволяла погода [3]. Англійський астроном Уільям Гершель також був зацікавлений у тому, як кількість плям на Сонці може впливати на розвиток рослин. Щоб внести ясність у дане питання, Гершель зіставив зібрані ним дані про сонячні плями майже за двісті років із ринковими цінами на пшеницю. Зв'язок виявився досить простим i чітким - ціни були тим меншими, чим вищою була сонячна активність. За високої сонячної активності клімат стає більш вологішим, тому врожаї пшениці кращі, а ринкові ціни на неї нижчі [16].

Число плям на диску Сонця не є постійним, воно змінюється як $з о$ дня на день, так і протягом більш тривалих проміжків часу.

Німецький астроном-любитель Генріх Швабе, який 17 років вів систематичні спостереження сонячних плям, помітив, що їх кількість зменшується від максимуму до мінімуму, а потім збільшується до максимального значення за період близько 10 років. Водночас у максимумі на сонячному диску можна бачити 100 і більше плям, тоді як у мінімумі - всього декілька, а іноді протягом цілих тижнів не спостерігалося жодного. Повідомлення про своє відкриття Швабе опублікував у 1843 році.

Швейцарський астроном Рудольф Вольф пояснив, що середній період зміни числа плям складає не 10, а 11 років. Він же запропонував для кількісної оцінки активності Сонця використовувати умовну величину, яка 3 тих пір називається числом Вольфа (W). Воно визначається як сума загальної кількості плям на Сонці (f) та збільшеного у 10 разів числа груп плям (g), водночас ізольована одинична пляма також вважається групою і коефіцієнтом k, що приводить спо- 


\section{СІЛЬСЬКЕ ГОСПОДАРСТВО. РОСЛИННИЦТВО}

стережені величини до стандартних цюрихських чисел $[6,13]$ :

$$
W=k(f+10 g)
$$

Аналіз останніх досліджень та публікацій, у яких започатковано розв'язання проблеми. Як було викладено вище, проблема впливу сонячної активності на врожайність сільськогосподарських культур досліджувалась ще в давнину. У $\mathrm{XX}$ ст. одним із перших, хто досліджував дане питання в рамках впливу сонячної активності на земне життя був О. Л. Чижевський [15].

Але інтерес до цієї проблематики існує і дотепер. Найбільше сонячна активність впливає на врожайність через клімат і погодні умови, а також на розмноження і життєдіяльність багатьох шкідників сільськогосподарських рослин [5, 14]. Останні роботи, з якими ми познайомилися та в яких висвітлюється проблема впливу циклічності сонячної і місячної активності на врожайність озимого жита і ярого ячменю, були дослідження М. П. Кушніра $[8,9]$.

Метою досліджень було встановити залежність формування врожайності сільськогосподарських культур від сонячної активності та можливість подальшого застосування цієї залежності у прогнозах очікуваної врожайності.

Завдання дослідження - на основі побудованих графіків та проведеного кореляційного аналізу проаналізувати залежність формування врожайності сільськогосподарських культур від сонячної активності.
Методика проведення дослідження. Усі графіки та статистична обробка методом кореляційного аналізу були виконані 3 використанням пакетів Excel.

Матеріали досліджень. Матеріалом для дослідження стали статистичні дані врожайності різних сільськогосподарських культур (у ц/га) Головного управління статистики у Полтавській області та статистичні дані середньомісячної сонячної активності (чисел Вольфа) взяті $з$ джерел [7, 17]. Статистичні дані охоплюють період 3 1966 (65) року по 2012 рік включно.

Результати досліджень. На основі проаналізованих статистичних даних побудовано графіки середніх значень врожайності сільськогосподарських культур з 25-ти районів Полтавської області та середніх значень середньомісячних чисел Вольфа за відповідний вегетаційний період культур.

На графіку (рис. 1) представлено середню врожайність усіх зернових культур, включаючи кукурудзу у Полтавській області (крива 1) та середнє значення середньомісячних чисел Вольфа за вегетаційний період зернових культур (крива 2). Для побудови графіка реальні числа Вольфа зменшено у три рази. До зернових культур належать пшениця, жито, ячмінь, кукурудза, овес, просо, гречка та інші. Так як зернові культури включають і озимі, і ярі та круп'яні культури, то вегетаційний період рівний 12 місяцям (останні 4 місяці попереднього року, починаючи з 1965 року та перші 8 місяців реперного року - 1966 року і т. д.).

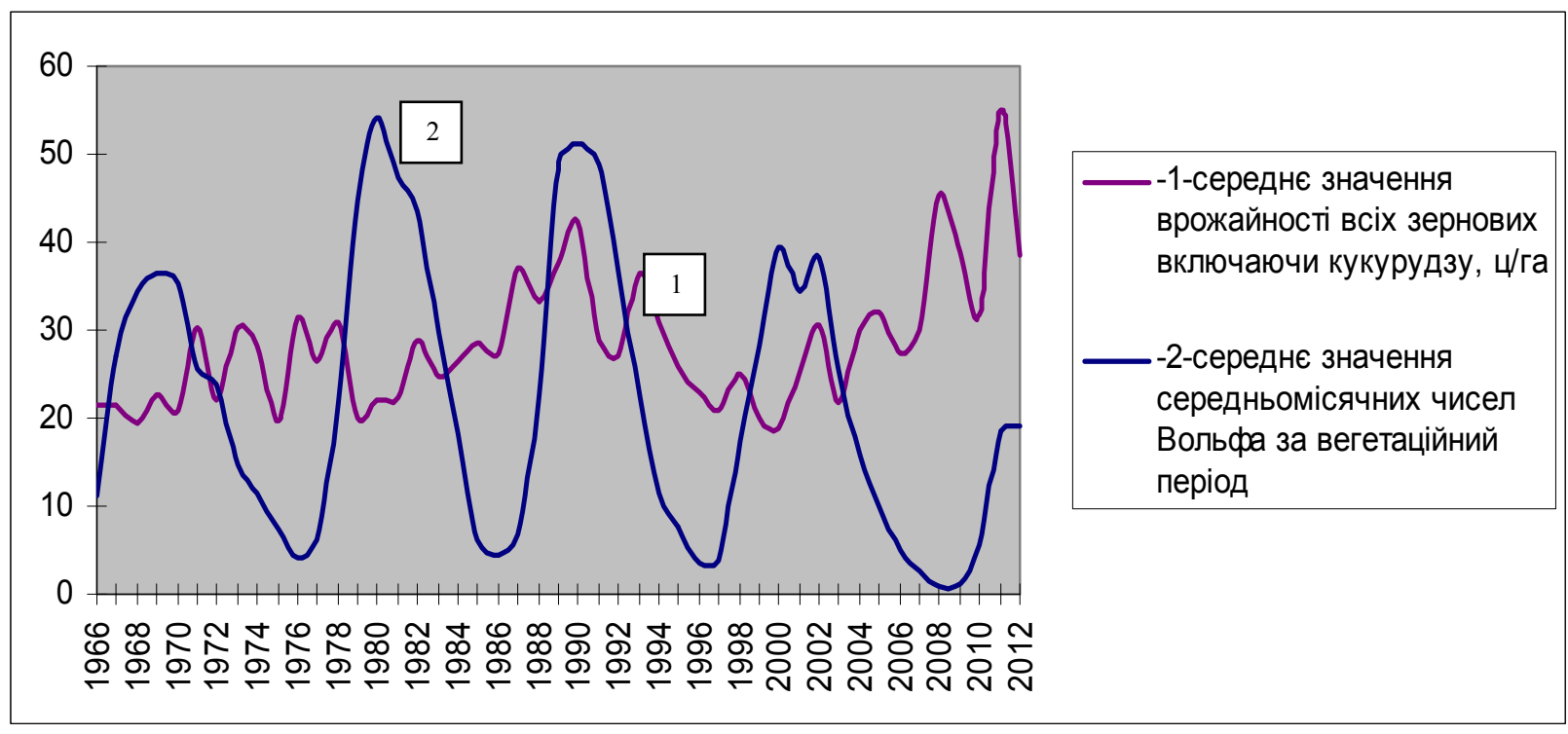

Рис. 1. Середня врожайність зернових культур, включаючи кукурудзу та середнє значення середньомісячних чисел Вольфа за вегетаційний період зернових у Полтавській області за 1966-2012 рр. 


\section{СІЛЬСЬКЕ ГОСПОДАРСТВО. РОСЛИННИЦТВО}

Врожайність змінюється набагато частіше, ніж сонячна активність, яка, в свою чергу, змінюється зі стабільним періодом приблизно 11 років, що відображено на графіках. На графіку (рис. 1) можемо побачити співпадання піків урожайності зернових культур та сонячної активності у 1990 році та у 2002 році, а також нечітке співпадання піків у 1969 році та у 2011 році. Досить високий пік сонячної активності у 1980 році не співпадає 3 піком урожайності у 1976 році.

Пшениця - найважливіша продовольча культура [10]. На графіку (рис. 2) представлено середню врожайність озимої пшениці у Полтавській області (крива 1) та середнє значення середньомісячних чисел Вольфа за вегетаційний період озимої пшениці (крива 2). Для побудови графіка реальні числа Вольфа зменшено у три рази. Вегетаційний період озимої пшениці складає 200350 днів у залежності від регіону. Для умов лісостепу України, в якому знаходиться Полтавська область, вегетаційний період триває 290-310 днів, 3 вересня по липень - 10 місяців [10] (останні 4 місяці попереднього року, починаючи 31965 року та перші 6 місяців реперного року - 1966 року і т. д.). На графіку (рис. 2) можемо бачити співпадання піків урожайності озимої пшениці у 1990 році та у 2002 році, а також нечітке співпадання піків у 1969 році. Як і в графіку зернових культур, максимум сонячної активності у 1980 році не співпадає 3 максимумом урожайності озимої пшениці у 1978 році.

Жито - цінна продовольча, кормова і технічна культура [10]. На графіку (рис. 3) представлено середню врожайність озимого жита у Полтавській області (крива 1) та середнє значення середньомісячних чисел Вольфа за вегетаційний період озимого жита (крива 2). Для побудови графіка реальні числа Вольфа зменшено у п'ять разів. Вегетаційний період озимого жита становить 260-270 днів, 3 вересня по червень - 9 місяців [10] (останні 4 місяці попереднього року, починаючи з 1965 року та перші 5 місяців реперного року - 1966 року і т. д.). На графіку (рис. 3) можемо бачити співпадання піків урожайності озимого жита у 1990 році та у 2002 році, а також нечітке співпадання піків у 1969 році. Як і на графіку зернових культур, максимум сонячної активності у 1980 році не співпадає з максимумом урожайності озимого жита у 1973 році.

На графіку (рис. 4) представлено середню врожайність ярого ячменю (крива 1), проса (крива 2) і гречки (крива 3) у Полтавській області та середнє значення середньомісячних чисел Вольфа за відповідний вегетаційний період (крива 4). Для побудови графіка реальні числа Вольфа зменшено у п'ять разів. Вегетаційний період ярого ячменю, проса і гречки майже однаковий i становить 60-110 днів - 4 місяці [10]: травень, червень, липень і серпень (починаючи 31966 року i до 2012 року включно). На графіку (рис. 4) можемо бачити, що одні 3 максимумів врожайності ярого ячменю, проса і гречки у 1990 році не співпадають 3 максимумами сонячної активності у 1989 та 1991 роках. Це можна пояснити високим значенням сонячної активності саме в зимові та весняні місяці 1990 року, на які не припадає вегетаційний період даних сільськогосподарських культур. Тому у графіках озимих культур пік сонячної активності у 1990 році $\epsilon$ помітним, а у решти графіків він припадає на 1989 та 1991 роки.

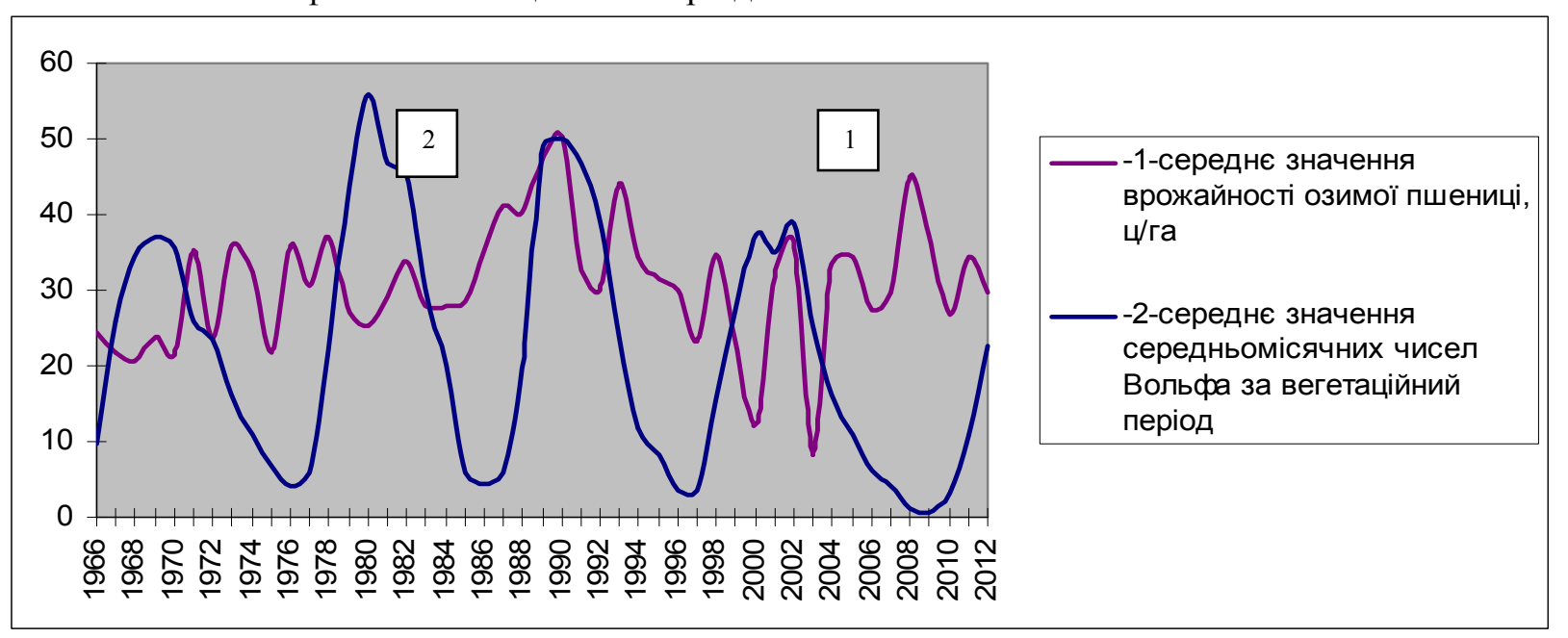

Рис. 2. Середня врожайність озимої пшениці та середнє значення середньомісячних чисел Вольфа за вегетаційний період озимої пшениці у Полтавській області за 1966-2012 рр. 


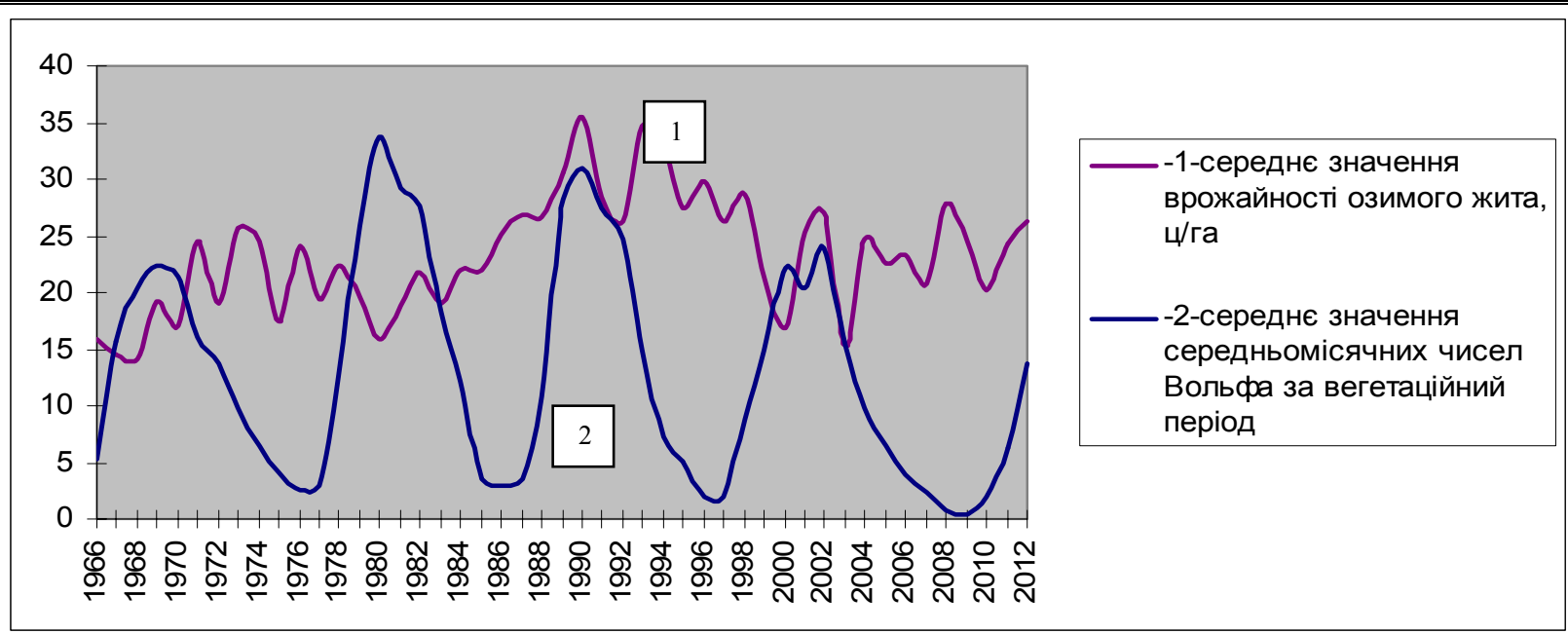

Рис. 3. Середня врожайність озимого жита та середнє значення середньомісячних чисел Вольфа за вететаційний період озимого жита у Полтавській області за 1966-2012 рр.

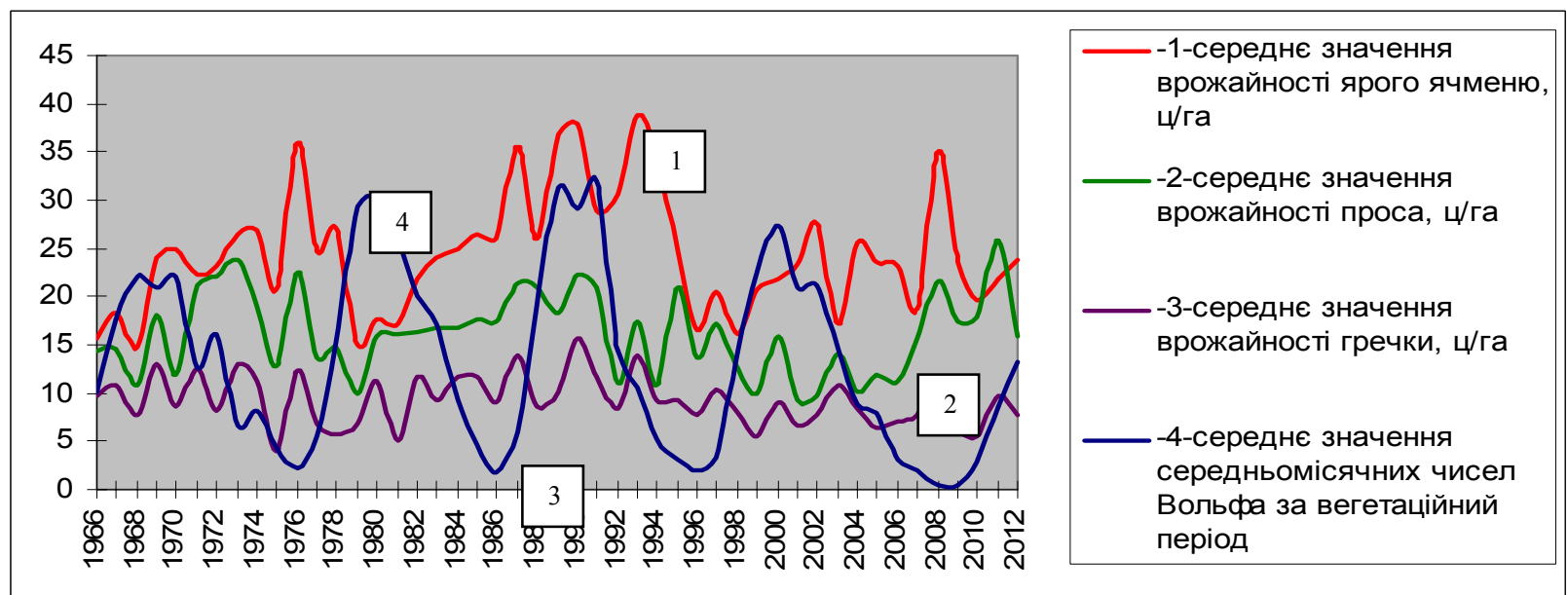

Рис. 4. Середня врожайність ярого ячменю, проса і гречки та середнє значення середньомісячних чисел Вольфа за відповідний вететаційний період у Полтавській області за 1966-2012 pр.

Таку ж картину спостерігаємо і у 1969 році. У 2000 році пік сонячної активності збігається 3 піками врожайності проса і гречки, але пік урожайності ярого ячменю переноситься на 2002 рік. Максимум сонячної активності у 1980 році не співпадає з максимумом урожайності ярого ячменю, проса і гречки у 1976 році.

На графіку (рис. 5) представлено середню врожайність кукурудзи у Полтавській області (крива 1) та середнє значення середньомісячних чисел Вольфа за вететаційний період кукурудзи (крива 2). Для побудови графіка реальні числа Вольфа зменшено у два рази. Вегетаційний період кукурудзи становить 90-200 днів, 4 місяці: травень, червень, липень, серпень [10]. На графіку (рис. 5) можемо побачити співпадання піків сонячної активності та врожайності кукурудзи у 2000 році.

У 1990 році спостерігається пік урожайності кукурудзи та пік сонячної активності випадає як у попередньому графіку за рахунок зимово- весняних місяців і переноситься на 1991 рік. Пік сонячної активності у 1980 році не співпадає 3 максимумом урожайності у 1977 році.

На графіку (рис. 6) представлено середню врожайність вівса у Полтавській області (крива 1) та середнє значення середньомісячних чисел Вольфа за вегетаційний період вівса (крива 2). Для побудови графіка реальні числа Вольфа зменшено у п'ять разів. Вегетаційний період вівса становить 5 місяців: квітень, травень, червень, липень, серпень [10].

На графіку (рис. 6) маємо нечітке співпадання піків сонячної активності та врожайності вівса у 1970 та 2000 році. У 1990 році спостерігається пік урожайності вівса та пік сонячної активності випадає як у попередньому графіку за рахунок зимово-весняних місяців і переноситься на 1991 рік. Пік сонячної активності у 1980 році не співпадає з одним із максимумів урожайності у 1976 році. 


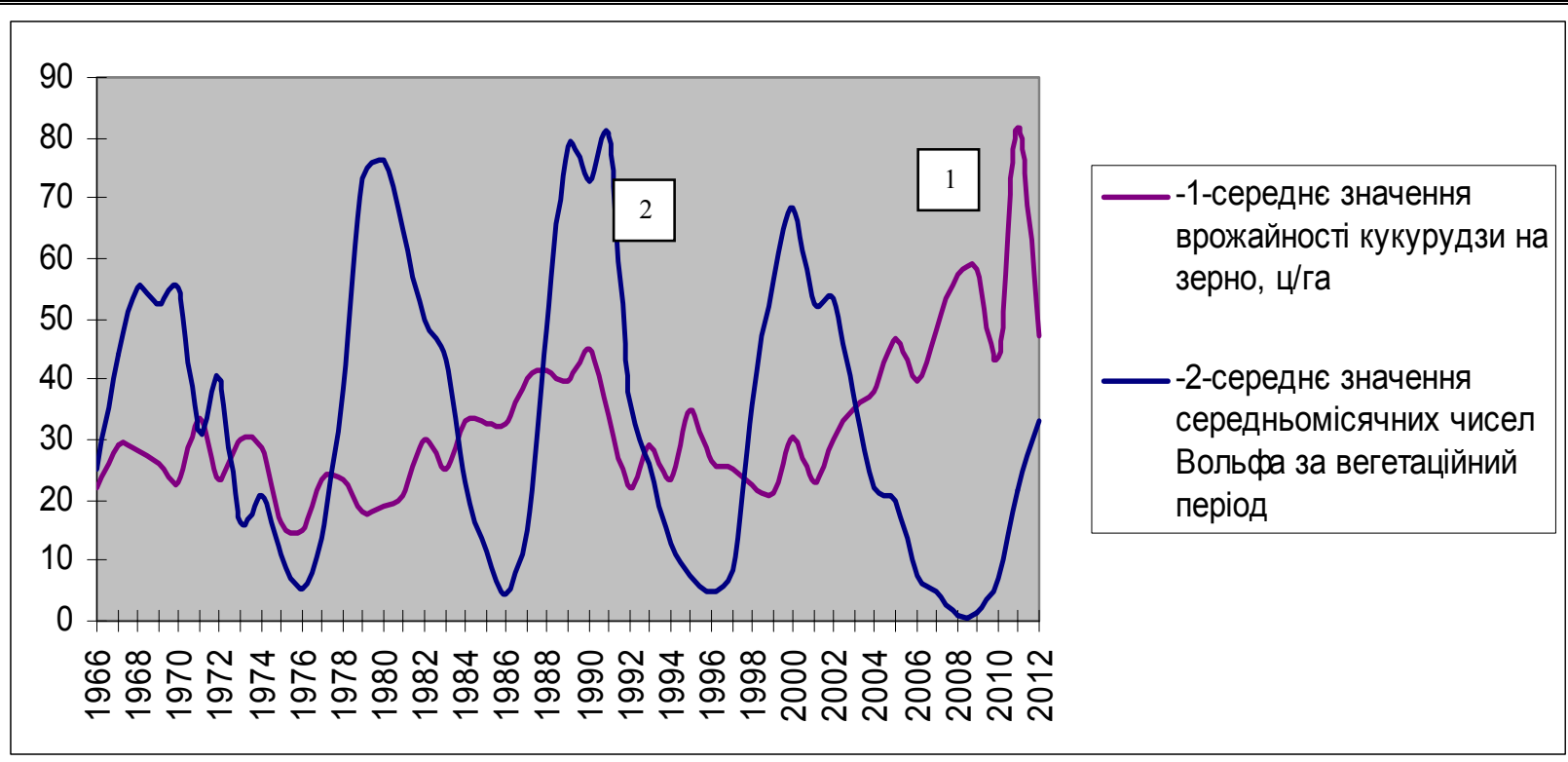

Рис. 5. Середня врожайність кукурудзи та середнс значення середньомісячних чисел Вольфа за вететаційний період кукурудзи у Полтавській області за 1966-2012 рр.

На графіку (рис. 7) представлено середню врожайність усіх зернобобових культур (крива 1) та гороху (крива 2) у Полтавській області та середнє значення середньомісячних чисел Вольфа за відповідний вегетаційний період (крива 3). Для побудови графіка реальні числа Вольфа зменшено у п'ять разів. Вегетаційний період зернобобових культур та, зокрема гороху, становить 7 місяців (так як можливо зібрати два врожаї за один рік): квітень, травень, червень, липень, серпень, вересень, жовтень [10]. Врожайності зернобобових культур та гороху дуже схожі, адже левову частку врожайності зернобобових становить саме горох. На графіку (рис. 7) можемо бачити нечітке співпадання піків сонячної актив- ності та врожайності зернобобових культур і гоpoxy у 1969 та 2000 роках. Пік сонячної активності припадає на 1989 рік, а пік урожайності зернобобових культур і гороху на 1990 рік. У 1980 році, коли спостерігається пік сонячної активності, у врожайності також виділяється невеликий пік, проте у 1976 році максимум урожайності набагато більший, що свідчить про неспівпадання піків.

На графіку (рис. 8) представлено середню врожайність соняшника у Полтавській області (крива 1) та середнє значення середньомісячних чисел Вольфа за вегетаційний період соняшника (крива 2). Для побудови графіка реальні числа Вольфа зменшено у шість разів.

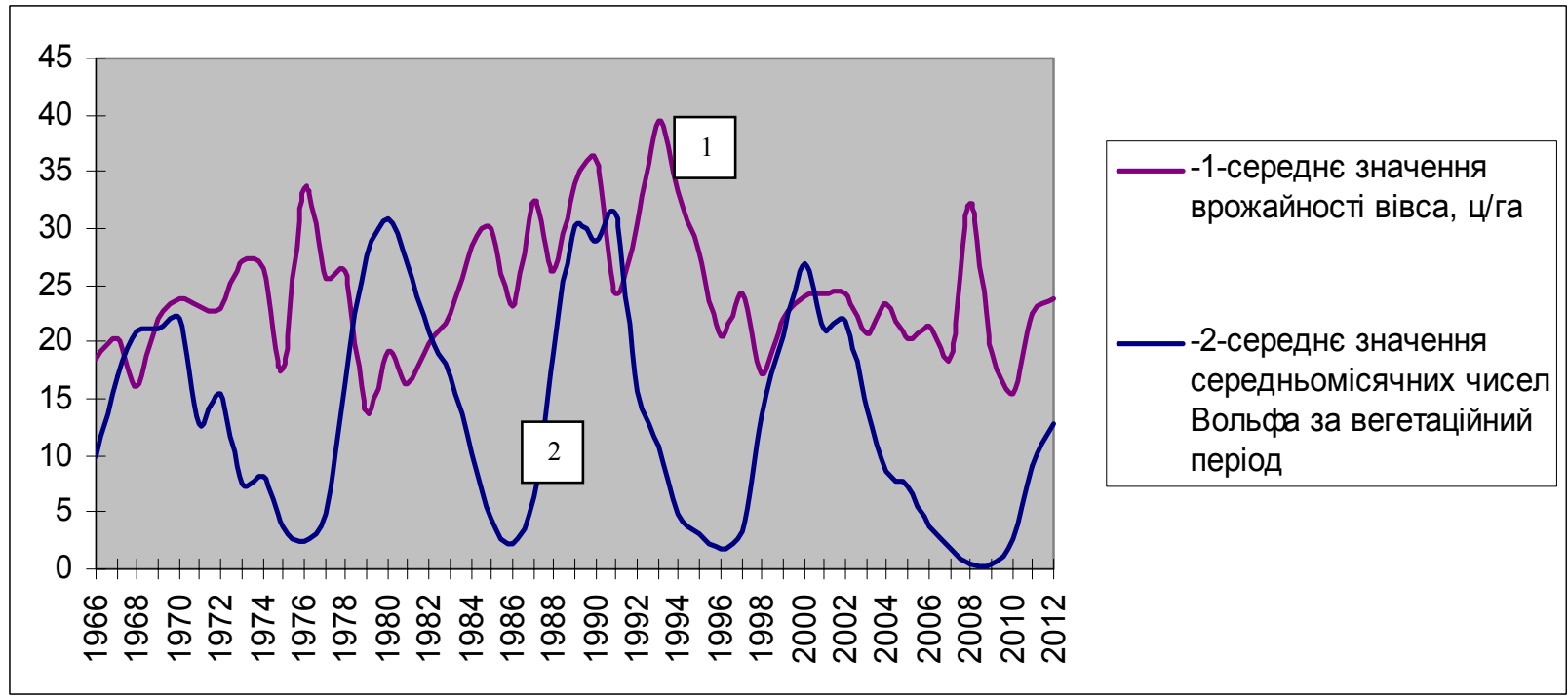

Рис. 6. Середня врожайність вівса та середнє значення середньомісячних чисел Вольфа за вететаційний період вівса у Полтавській області за 1966-2012 рр. 


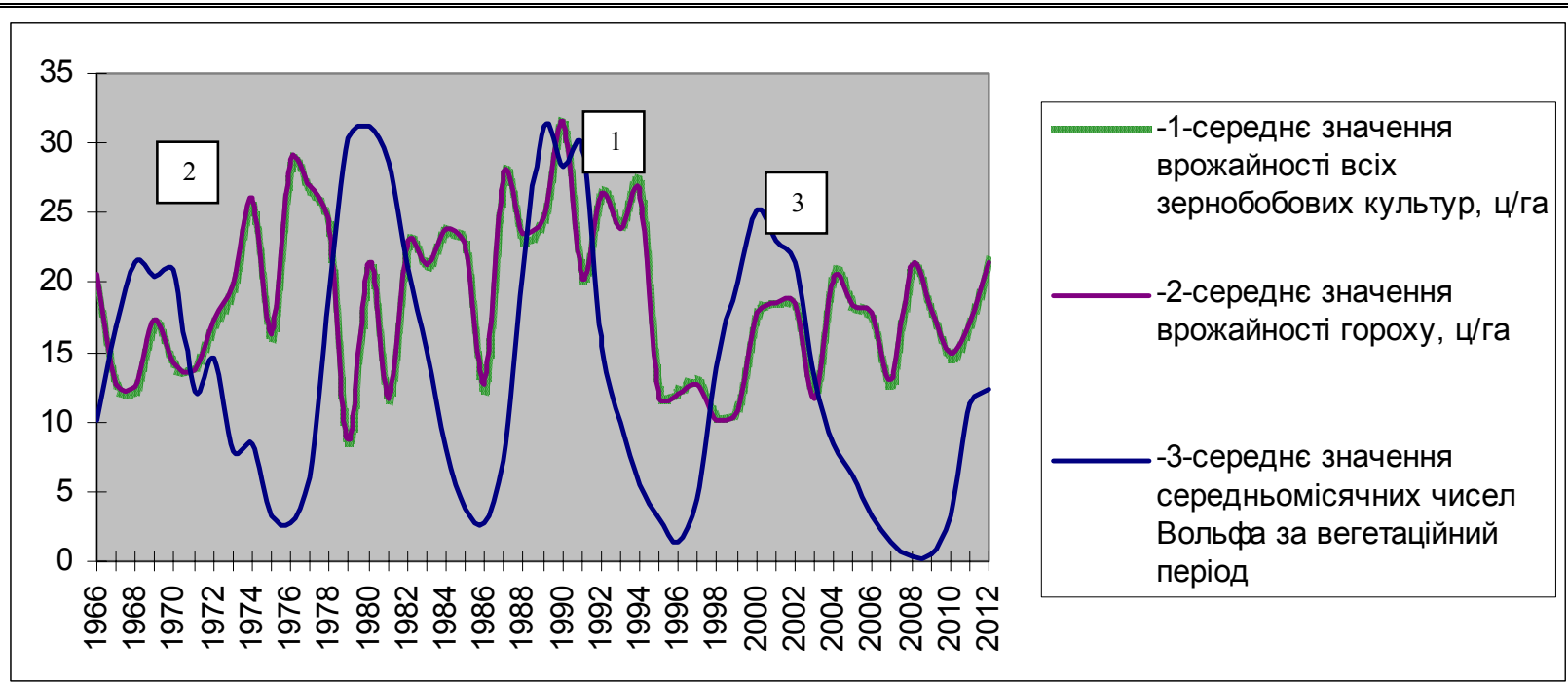

Рис. 7. Середня врожсайність усіх зернобобових культур і гороху та середнс значення середньомісячних чисел Вольфа за відповідний вететаційний період у Полтавській області за 1966-2012 рр.

Вегетаційний період соняшника становить 4 місяці: травень, червень, липень, серпень [10]. На графіку (рис. 8) можемо спостерігати збіг піку сонячної активності та невеликого піку врожайності соняшника у 2000 році. У 1990 році спостерігається пік урожайності соняшника та пік сонячної активності випадає як у попередніх графіках за рахунок зимово-весняних місяців i переноситься на 1991 рік. Пік сонячної активності у 1980 році не співпадає з одним із максимумів урожайності у 1974 році.

На графіку (рис. 9) представлено середню врожайність картоплі у Полтавській області (крива 1) та середне значення середньомісячних чисел Вольфа за вегетаційний період картоплі (крива 2).

Для побудови графіка реальні числа Вольфа не змінювалися. Вегетаційний період картоплі становить 4 місяці: травень, червень, липень, серпень [10].

На графіку (рис. 9) можемо бачити збіг піку сонячної активності та невеликого піку врожайності соняшника у 2000 році. У 1990 році спостерігається один із піків урожайності соняшника та пік сонячної активності припадає як у попередніх графіках за рахунок зимово-весняних місяців і переноситься на 1991 рік. Пік сонячної активності у 1980 році не співпадає з одним із максимумів урожайності у 1976 році.

На графіку (рис. 10) представлено середню врожайність цукрових буряків у Полтавській області (крива 1) та середнє значення середньомісячних чисел Вольфа за вегетаційний період цукрових буряків (крива 2).

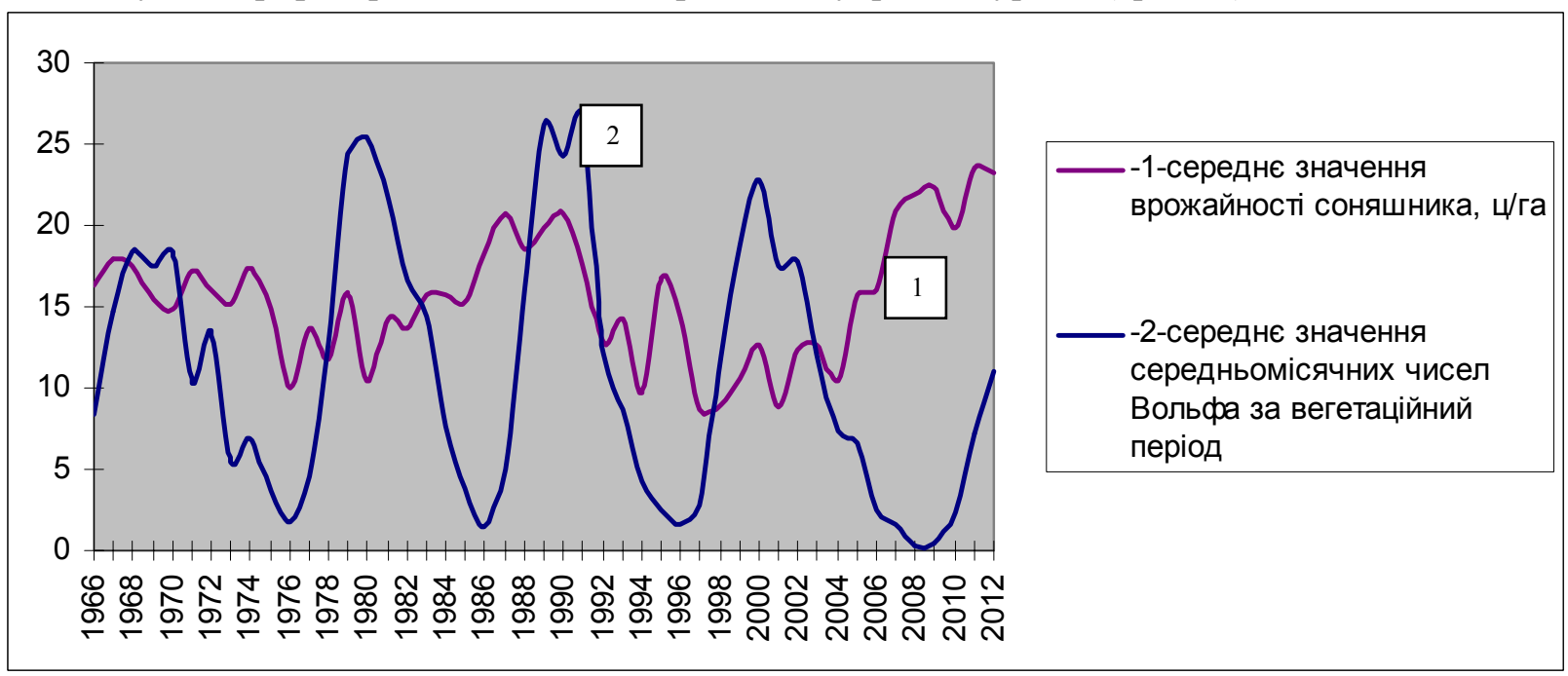

Рис. 8. Середня врожайність соняшника та середнє значення середньомісячних чисел Вольфа за вететаційний період соняшника у Полтавській області за 1966-2012 рр. 


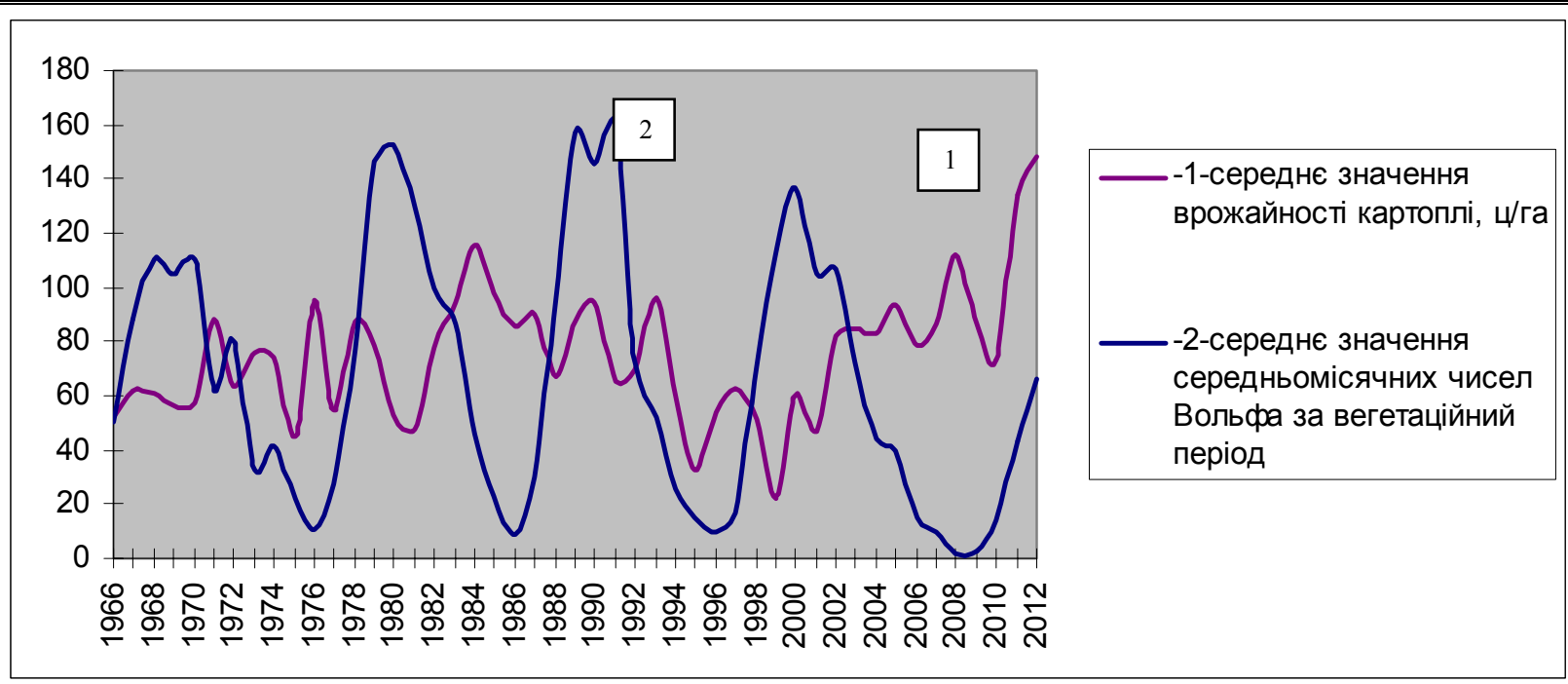

\section{Рис. 9. Середня врожайність картоплі та середнє значення середньомісячних чисел Вольфа} за вететаційний період картоплі у Полтавській області за 1966-2012 рр.

Для побудови графіка реальні числа Вольфа збільшено у два рази. Вегетаційний період цукрових буряків становить 7 місяців: квітень, травень, червень, липень, серпень, вересень, жовтень [10]. На графіку (рис. 10) можемо бачити збіг піків сонячної активності та врожайності цукрових буряків у 2012 році. У 1990 році спостерігається один із піків урожайності цукрових буряків та пік сонячної активності випадає як у попередніх графіках за рахунок зимових місяців і переноситься на 1989 рік.

Пік сонячної активності у 1980 році не співпадає з одним із максимумів урожайності у 1976 році, попри те, що у 1980 році невеликий пік урожайності збігається з сонячною активністю.

На графіку (рис. 11) представлено середню врожайність овочів у Полтавській області (крива 1) та середнє значення середньомісячних чисел Вольфа за вегетаційний період овочів (крива 2). Для побудови графіка реальні числа Вольфа не змінювалися. Вегетаційний період овочів становить 7 місяців: квітень, травень, червень, липень, серпень, вересень, жовтень.

На графіку (рис. 11) маємо збіг піків сонячної активності та невеликих піків урожайності овочів у 1968 та 2000 роках. У 1990 році спостерігається один із піків урожайності овочів та пік сонячної активності випадає як у попередніх графіках за рахунок зимових місяців і переноситься на 1989 рік. Пік сонячної активності у 1980 році не співпадає з одним із максимумів урожайності у 1976 році, попри те, що у 1980 році невеликий пік урожайності збігається з сонячною активністю.

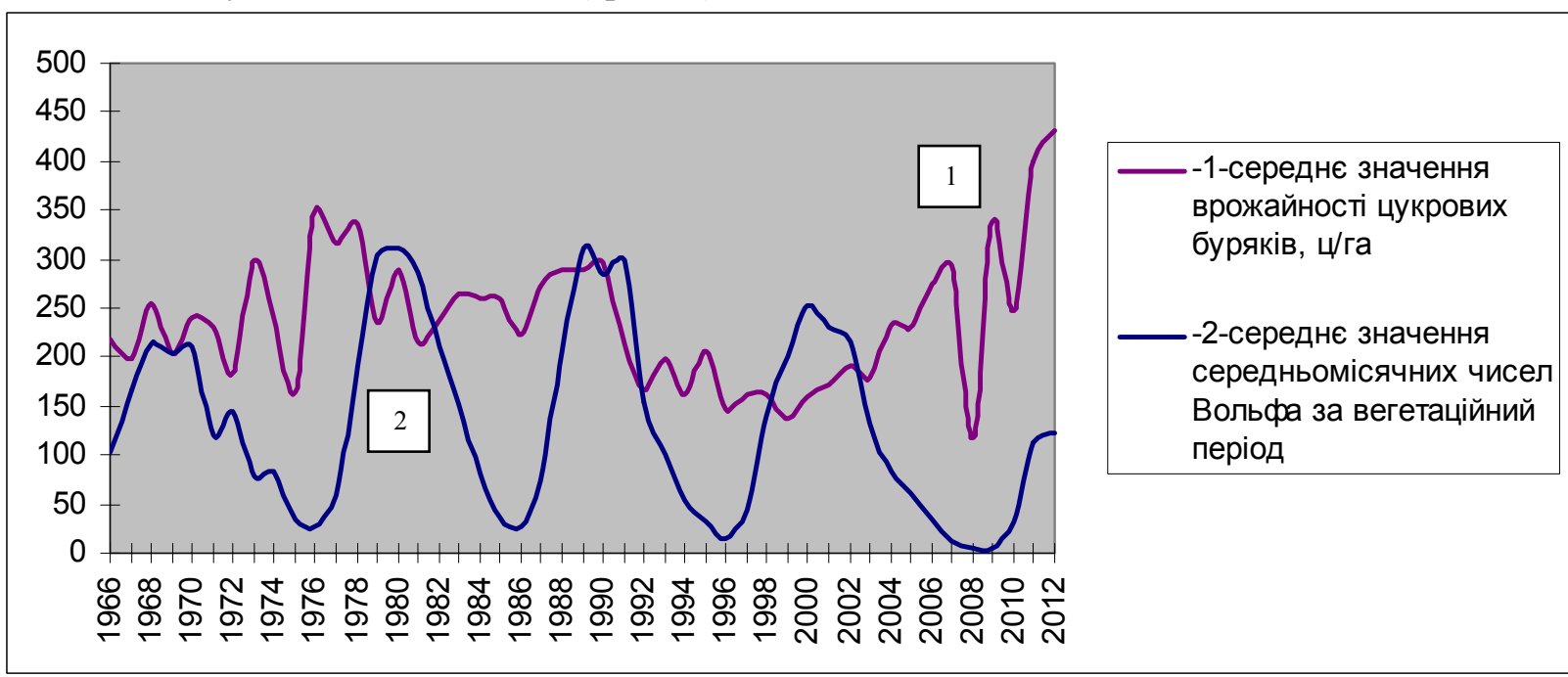

Рис. 10. Середня врожайність цукрових буряків та середнє значення середньомісячних чисел Вольфа за вететаційний період цукрових буряків у Полтавській області за 1966-2012 рр. 


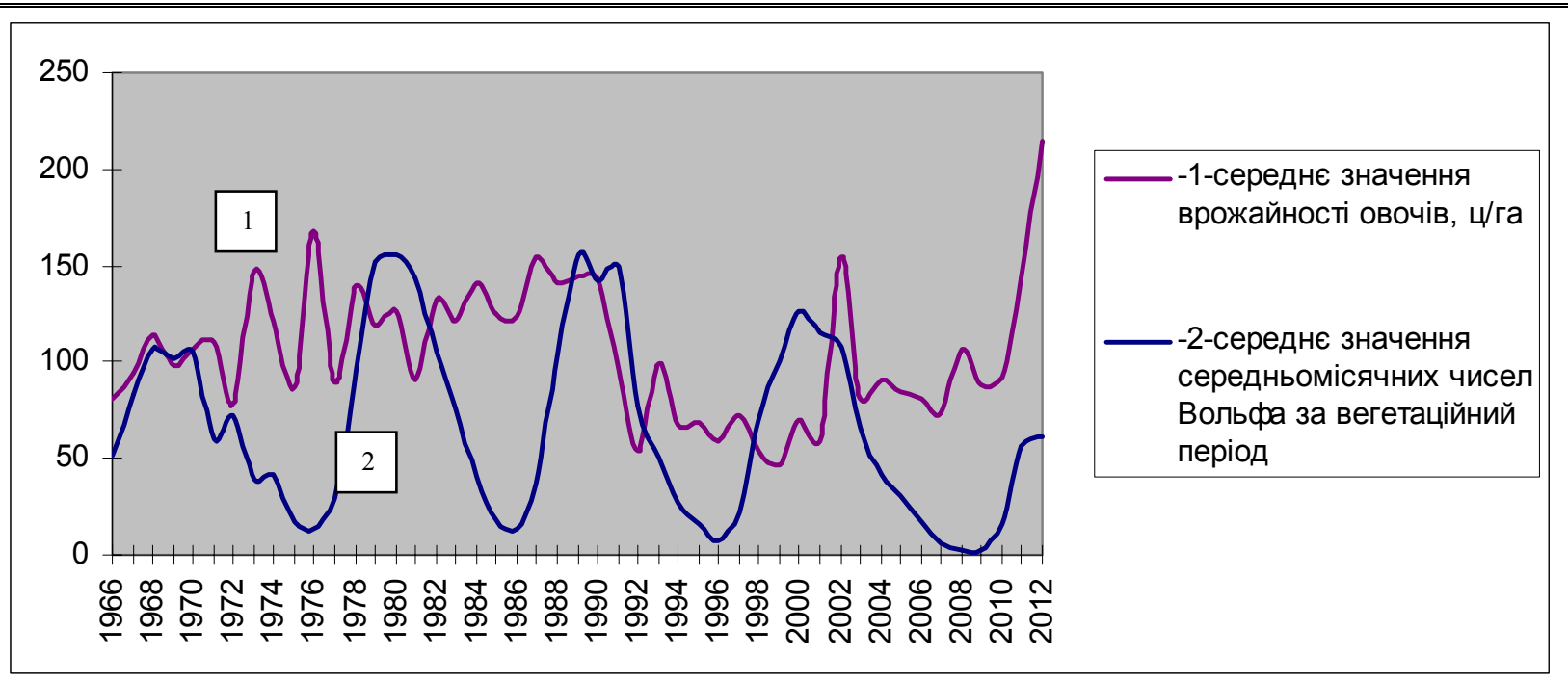

Рис. 11. Середня врожайність овочів та середн значення середньомісячних чисел Вольфа за вететаційний період овочів у Полтавській області за 1966-2012 pp.

У таблиці представлено результати кореляційного аналізу між сонячною активністю і врожайністю сільськогосподарських культур по кожному із сонячних циклів окремо. Обраний період дослідження 3 1966 року по 2012 рік включає майже весь 20-й, повністю 21-й, 22-й, 23-й і половину 24-го 11-річного циклу сонячної активності. Сірим кольором позначено роки початку і кінця сонячних циклів, які не ввійшли до періоду дослідження. Решіткою позначені додатні коефіцієнти кореляції більше 35 \% відповідності, зірочкою позначені коефіцієнти кореляції більше $35 \%$ відповідності з від’ємним знаком, не позначені коефіцієнти кореляції менше $35 \%$ відповідності незалежно від знаку.

Досить цікавим є той факт, що у 22-му циклі сонячної активності (1987-1996 рр.) абсолютно всі коефіцієнти кореляції додатні та всі, за винятком озимого жита, вівса і гречки, становлять більше 35 \% відповідності. У 20-му циклі сонячної активності (1965 (1966)-1976 рр.) всі коефіцієнти кореляції становлять більше 35 \% відповідності (за винятком гречки і цукрових буряків), але мають від'ємний знак, окрім коефіцієнтів кореляції для кукурудзи та соняшника. У 21-му циклі сонячної активності (1977-1986 рр.) абсолютно всі коефіцієнти кореляції є від'ємними та з більше $35 \%$ відповідності, крім гречки, овочів та цукрових буряків. У 23-му циклі сонячної активності (1997-2007рp.) коефіцієнти кореляції становлять менше $35 \%$ відповідності за винятком картоплі, кукурудзи, вівса, соняшника і цукрових буряків. Причому додатні коефіцієнти кореляції спостерігаються тільки для всіх зернобобових культур, гороху, вівса, овочів та ярого ячменю. У 24-му циклі сонячної активності (20082012 (2018) pр.) коефіцієнти кореляції є додатні- ми для всіх зернобобових культур, зернових культур, гороху, гречки, озимого жита, картоплі, кукурудзи, овочів, соняшника, цукрових буряків, до того ж для всіх зернових культур, картоплі, овочів, соняшника і цукрових буряків - більше $35 \%$ відповідності; та від'ємними для вівса, проса, озимої пшениці і ярого ячменю, водночас для останніх двох культур - більше 35 \% відповідності. Останній 3 наведених циклів сонячної активності ще не завершений, його кінець прогнозований на 2018 рік. У рамках вибраного періоду дослідження, 2012 рік був роком максимуму сонячної активності. Тому, кореляційний аналіз по 24-му циклу сонячної активності є не досить достовірним, так як цикл ще не закінчився і ми розглядаємо тільки половину циклу. Більше 100 років тому Дж. Хейл відкрив магнітні поля на Сонці у плямах. Було показано, що під час переходу від одного 11-річного циклу до наступного полярність магнітного поля в сонячних плямах в обох півкулях змінюється на протилежну. Знак магнітного поля плям зберігається протягом 11річного циклу з невеликими виключеннями. Кожний 22-річний магнітний цикл складається 3 двох 11-річних, під час цього кожна нова пара циклів починається 3 парного 11-річного. Зміна полярності магнітного поля плям засвідчує про взаємозв'язок активності між різними півкулями Сонця у сусідніх циклах [1].

Одинадцятирічний цикл сонячної активності є відображенням циклічної зміни крупномасштабного магнітного поля Сонця. В ході цього циклу змінюється не тільки число та інтенсивність різноманітних проявів сонячної активності, але і їх розподіл по поверхні Сонця. 
СІЛЬСЬКЕ ГОСПОДАРСТВО. РОСЛИННИЦТВО

\section{Коефіцієнт кореляції міжс сонячною активністю і врожайністю сільськогосподарських культур по кожному із сонячних циклів}

\begin{tabular}{|c|c|c|}
\hline Цикли сонячної активності & Культури & Коефіцієнт кореляції \\
\hline 1 & 2 & 3 \\
\hline \multirow{14}{*}{$\begin{array}{c}\text { 20-й цикл } \\
\text { (1965 (1966)-1976 рр.) }\end{array}$} & Всі зернобобові & $-0,68203^{*}$ \\
\hline & Всі зернові+кукурудза & $-0,44497^{*}$ \\
\hline & Горох & $-0,68272^{*}$ \\
\hline & Гречка & $-0,04475$ \\
\hline & Жито озиме & $-0,37175^{*}$ \\
\hline & Картопля & $-0,39798^{*}$ \\
\hline & Кукурудза на зерно & $0,418646 \#$ \\
\hline & Овес & $-0,43573^{*}$ \\
\hline & Овочі & $-0,38663^{*}$ \\
\hline & Просо & $-0,47472 *$ \\
\hline & Пшениця озима & $-0,46251 *$ \\
\hline & Соняшник & $0,516424 \#$ \\
\hline & Цукрові буряки & $-0,28662$ \\
\hline & Ячмінь ярий & $-0,49467^{*}$ \\
\hline \multirow{14}{*}{$\begin{array}{c}\text { 21-й цикл } \\
\text { (1977-1986 pp.) }\end{array}$} & Всі зернобобові & $-0,39693 *$ \\
\hline & Всі зернові+кукурудза & $-0,62107^{*}$ \\
\hline & Горох & $-0,4043 *$ \\
\hline & Гречка & $-0,1863$ \\
\hline & Жито озиме & $-0,65852 *$ \\
\hline & Картопля & $-0,47455^{*}$ \\
\hline & Кукурудза на зерно & $-0,78193^{*}$ \\
\hline & Овес & $-0,80054 *$ \\
\hline & Овочі & $-0,08762$ \\
\hline & Просо & $-0,45095^{*}$ \\
\hline & Пшениця озима & $-0,39545^{*}$ \\
\hline & Соняшник & $-0,49048^{*}$ \\
\hline & Цукрові буряки & $-0,12382$ \\
\hline & Ячмінь ярий & $-0,87655^{*}$ \\
\hline \multirow{14}{*}{$\begin{array}{c}\text { 22-й цикл } \\
\text { (1987-1996 pp.) }\end{array}$} & Всі зернобобові & $0,448808 \#$ \\
\hline & Всі зернові+кукурудза & $0,464366 \#$ \\
\hline & Горох & $0,46708 \#$ \\
\hline & Гречка & 0,320794 \\
\hline & Жито озиме & 0,263126 \\
\hline & Картопля & $0,453287 \#$ \\
\hline & Кукурудза на зерно & $0,514467 \#$ \\
\hline & Овес & 0,152978 \\
\hline & Овочі & $0,548346 \#$ \\
\hline & Просо & $0,406402 \#$ \\
\hline & Пшениця озима & $0,437075 \#$ \\
\hline & Соняшник & $0,525616 \#$ \\
\hline & Цукрові буряки & $0,631834 \#$ \\
\hline & Ячмінь ярий & $0,369294 \#$ \\
\hline \multirow{14}{*}{$\begin{array}{c}\text { 23-й цикл } \\
\text { (1997-2007 pр.) }\end{array}$} & Всі зернобобові & 0,111781 \\
\hline & Всі зернові+кукурудза & $-0,33382$ \\
\hline & Горох & 0,095453 \\
\hline & Гречка & $-0,16223$ \\
\hline & Жито озиме & $-0,17356$ \\
\hline & Картопля & $-0,54784 *$ \\
\hline & Кукурудза на зерно & $-0,60166^{*}$ \\
\hline & Овес & $0,415277 \#$ \\
\hline & Овочі & 0,037322 \\
\hline & Просо & $-0,32367$ \\
\hline & Пшениця озима & $-0,18011$ \\
\hline & Соняшник & $-0,44505^{*}$ \\
\hline & Цукрові буряки & $-0,72908^{*}$ \\
\hline & Ячмінь ярий & 0,136759 \\
\hline
\end{tabular}


СІЛЬСЬКЕ ГОСПОДАРСТВО. РОСЛИННИЦТВО

\begin{tabular}{|c|c|c|}
\hline & & Продовження таблиичі \\
\hline 1 & 2 & 3 \\
\hline \multirow{14}{*}{$\begin{array}{c}\text { 24-й цикл } \\
\text { (2008-2012 (2018) pp.) }\end{array}$} & Всі зернобобові & 0,168705 \\
\hline & Всі зернові+кукурудза & $0,383854 \#$ \\
\hline & Гopox & 0,114108 \\
\hline & Гречка & 0,001595 \\
\hline & Жито озиме & 0,229996 \\
\hline & Картопля & $0,815499 \#$ \\
\hline & Кукурудза на зерно & 0,083891 \\
\hline & Овес & $-0,01308$ \\
\hline & Овочі & $0,8734 \#$ \\
\hline & Просо & $-0,05252$ \\
\hline & Пшениця озима & $-0,47755^{*}$ \\
\hline & Соняшник & $0,577131 \#$ \\
\hline & Цукрові буряки & $0,78861 \#$ \\
\hline & Ячмінь ярий & $-0,37075^{*}$ \\
\hline
\end{tabular}

Великий інтерес представляє проблема виникнення довготної асиметрії розподілу сонячної активності. Магнітний цикл Сонця, що включає два 11-річних цикли, проявляється не тільки у зміні полярності загального магнітного поля Сонця (ЗМПС), але і в зміні полярності основних плям (цикл Хейла). Два характерних періоди відповідають різним ситуаціям, які зустрічаються в 22-річному магнітному циклі Сонця, в ході якого глобальна полярність магнітного поля і полярність основної сонячної плями може бути однаковою (в даній сонячній півкулі) або протилежною. Для фази підйому-максимума полярності глобального магнітного поля і полярності основної сонячної плями співпадають; для фази спадумінімума - полярності протилежні [2].

Сонячна активність лише в грубому наближенні однаково проявляється в обох півкулях Сонця. Однак детальне вивчення різних індексів активності показує, що існує достатньо значна північно-південна асиметрія, тобто спостерігається «несинхронність роботи» північної і південної півкуль Сонця. В масштабах 11-річного циклу активності (розглядається тільки плямоутворююча діяльність Сонця) ця асиметрія зводиться, перш за все, до надлишку сумарної площі і числа груп плям в одній із півкуль, відмінності екстремумів і форми кривих 11-річних циклів в різних півкулях [12].

Стійкий характер асиметрії довготного розподілу магнітних полів, тісний зв'язок з фазою сонячного циклу дозволяє зробити висновок про закономірне виникнення такої асиметрії у ході сонячного циклу [2].

Дана характеристика магнітного циклу Сонця, полярності та асиметрії розподілу магнітних полів Сонця, дає вагомі причини стверджувати про своєрідний характер впливу сонячної активності на врожайність сільськогосподарських культур. Якщо говорити про цикл Хейла, який включає два 11-річних цикли сонячної активності, то можна зробити висновок, що схожими $є$ не кожні 3 11-річних циклів, а кожні через один 11-річний цикл. Так, подібними мають бути 20-й, 22-й, 24-й та 21-й і 23-й 11-річні цикли сонячної активності. Однак якщо у 22-му циклі сонячної активності ми спостерігаємо доволі високу схожість результатів кореляційного аналізу та ще й по всім культурам $з$ додатнім знаком, то аналогічної картини у 20-му та 24-му циклі ми не спостерігаємо. Кожен цикл сонячної активності має свої особливості [11]. 20-й цикл та перша половина 24-го 11-річного циклу сонячної активності характеризуються малими індексами сонячної активності (числами Вольфа), що відображено у графіках. Найімовірніше, це провокує низьку або від’ємну кореляцію між сонячною активністю та показниками врожайності сільськогосподарських культур. Що ж стосується 21-го та 23-го циклів сонячної активності, то врожайність у ці роки йде у повний різнобій з числами Вольфа, що відображають коефіцієнти кореляції. Це зайвий раз доводить, що у випадку з урожайністю сільськогосподарських культур, максимуми врожайності можуть спричинятися максимумами сонячної активності, але потрібно розглядати не 11-річний цикл сонячної активності та сонячну активність як суцільне явище, а обов'язково брати до уваги 22-річний магнітний цикл Сонця та особливості кожного циклу сонячної активності окремо.

\section{Висновки:}

1. На основі побудованих графіків урожайності сільськогосподарських культур і середніх значень середньомісячних чисел Вольфа за вегетаційний період виявлено співпадання піків урожайності та сонячної активності у 1989-1991 pp. 


\section{СІЛЬСЬКЕ ГОСПОДАРСТВО. РОСЛИННИЦТВО}

по всім сільськогосподарським культурам, а також нечітке співпадання невеликих піків у 1968 1970 роках і у 2000-2002 роках. Встановлено, що максимум урожайності у порівнянні з піком сонячної активності по всім культурам переноситься з 1980 року на 1973-1978 роки.

2. Коефіцієнти кореляції між сонячною активністю та врожайністю сільськогосподарських культур у 22-му 11-річному циклі сонячної активності мають додатні значення по всім культурам та складають більше 35 \% відповідності

\section{БІБЛІОГРАФІЯ}

1. Вариации глобальных характеристик Солнца / [Атрощенко И. Н., Гадун А. С., Гопасюк С. И. и др. ; под ред. Гуртовенко Э. А.]. - К. : Наукова думка, 1991. - 304 с.

2. Вернова E. C. Магнитный цикл Солнца: особености распределения фотосферного поля / Е. С. Вернова, М. И. Тясто, Д. Г. Баранов // Солнечно-земная физика. - 2008. - Т.1, Вып.12. C. $30-31$.

3. Витинский Ю. И. Солнечная активность / Ю. И. Витинский. - [2-е изд., перераб. и доп.]. М. : Наука, 1983. - 192 с.

4. Владимирский Б. М. Влияет ли «космическая погода» на общественную жизнь? / Б. М. Владимирский // Солнечно-земная физика. Политика и экогеодинамика регионов. - 2005. - Вып.2. C. 23-30.

5. Владимирский Б. М. Солнечно-биосферные связи. Полвека спустя после А. Л. Чижевского / Б. М. Владимирский // История и современность. - Вып.2(10). - 2009. - С. 119-131.

6. Герман Дж. Р. Солнце, погода и климат / Дж. Р. Герман, Р. А. Голдберг ; [пер. с англ. А. И. Оля и А. В. Цветкова ; под ред. К. Я. Кондратьева, В. Ф. Логинова]. - Л. : Гидрометеоиздат, 1981. - $320 \mathrm{c.}$

7. Ииков В. Н. 22-й цикл солнечной активности: основные свойства и ход развития [Електронний ресурс] / В. Н. Ишков // Астрономический сайт «Галактика». - 2003. - С. 37. - Режим доступу : http://www.moscowaleks.narod.ru/galaxy 37.html.

8. Кушнір П. М. Біоритмологія та закономірності руху врожайності в беззмінному посіві жита озимого на Полтавській сільськогосподарській дослідній станції / П. М. Кушнір. - Полтава : РВВ ПДАА, 2010. - 57 с.

9. Кушнір П. М. Закономірності руху врожаю сільськогосподарських культур в агроекологічних умовах України / П. М. Кушнір. - К. : вид-во ПП Клевцова Г. С., 2001. - 96 с. по всім культурам (за винятком трьох із чотирнадцяти).

3. Максимуми врожайності спричиняються максимумами сонячної активності, проте механізм впливу сонячної активності на врожайність $\epsilon$ набагато складнішим. Потрібно розглядати не 11-річний цикл сонячної активності та сонячну активність, як суцільне явище, а обов'язково брати до уваги 22-річний магнітний цикл Сонця та особливості кожного циклу сонячної активності незалежно один від одного.

10. Лихочвор В. В. Рослинництво. Технології вирощування сільськогосподарських культур / В. В. Лихочвор. - [2-е видання, виправлене]. - К. : Центр навчальної літератури, 2004. - 808 с.

11. Обридко В. Н. Циклы солнечной активности: состояние проблемы, основные механизмы, прогноз / В. Н. Обридко // Космическая погода и её роль в формировании свойств локальной среды. - 2013. - Т.1, Ч.1. - С. 28-45.

12. Олемской С. В. Статистические свойства и физическое моделирование солнечных пятен [Електронний ресурс] : автореф. дис. на соиск. учен. степ. к. ф.-м. н. : спец. 01.03 .03 «Физика Солнца» / С. В. Олемской. - Иркутск, 2006. - 18 с. - Режим доступу : www.dissercat. com/content/ statisticheskie-svoistva-i-fizicheskoe-modelirovaniesolnechnykh-pyaten.

13. Солнечная и солнечно-земная физика. Иллюстрированный словарь терминов / [под ред. А. Бруцека и Ш. Дюрана ; пер. с англ. Е. В. Иванова / под ред. Я. И. Фильдштейна и В. Н. Обридко]. - М. : Мир, 1980. - 256 с.

14. Солнечно-земные связи, погода и климат [Б. Мак-Кормак, Т. Селига, У. Робертс и др. ; пер. с англ. / под ред. Б. Мак-Кормака, Т. Селиги]. - М. : Мир, 1982. - 384 с.

15. Чижевский $А$. Л. Земное эхо солнечных бурь / А. Л. Чижевский. - [2-е изд.]. - М. : Мысль, 1976. - 367 с.

16. Ягодинский В. Н. Александр Леонидович Чижевский / В. Н. Ягодинский. - М. : Наука, 1987. $-320 \mathrm{c}$.

17. SIDC - Solar Influences Data Analysis Center [Електронний ресурс]. - Режим доступу : www.sidc.oma.be/sunspots/bulletins/ mounthly. 